\title{
Lucien Bianco, Stalin and Mao: A Comparison of the
} Russian and Chinese Revolutions,

Hong Kong, The Chinese University Press, 2018, xxv + 448 pp.

\section{Igor Iwo Chabrowski}

\section{OpenEdition}

\section{Journals}

\section{Electronic version}

URL: http://journals.openedition.org/chinaperspectives/8252

DOI: $10.4000 /$ chinaperspectives.8252

ISSN: 1996-4617

Publisher

Centre d'étude français sur la Chine contemporaine

\section{Printed version}

Date of publication: 1 September 2018

Number of pages: 83-84

ISSN: 2070-3449

\section{Electronic reference}

Igor Iwo Chabrowski, «Lucien Bianco, Stalin and Mao: A Comparison of the Russian and Chinese Revolutions, ", China Perspectives [Online], 2018/3 | 2018, Online since 01 September 2018, connection on 10 December 2020. URL : http://journals.openedition.org/chinaperspectives/8252 ; DOI : https:// doi.org/10.4000/chinaperspectives.8252

This text was automatically generated on 10 December 2020 .

(c) All rights reserved 


\section{Lucien Bianco, Stalin and Mao: A Comparison of the Russian and Chinese Revolutions,}

Hong Kong, The Chinese University Press, 2018, xxv + 448 pp.

Igor Iwo Chabrowski

1 Lucien Bianco's newly translated book Stalin and Mao: A Comparison of the Russian and Chinese Revolutions is a masterful work of comparative history. Painted in broad strokes, strongly worded, and not shying away from negative judgments, this book represents both an excellent narrative of the twentieth century history of the two largest communist countries, and the author's horror with the direction the communist movement took in the hands of Stalin and Mao.

2 It is worth noting that the English translation published by the Chinese University Press differs in minor respects from the French

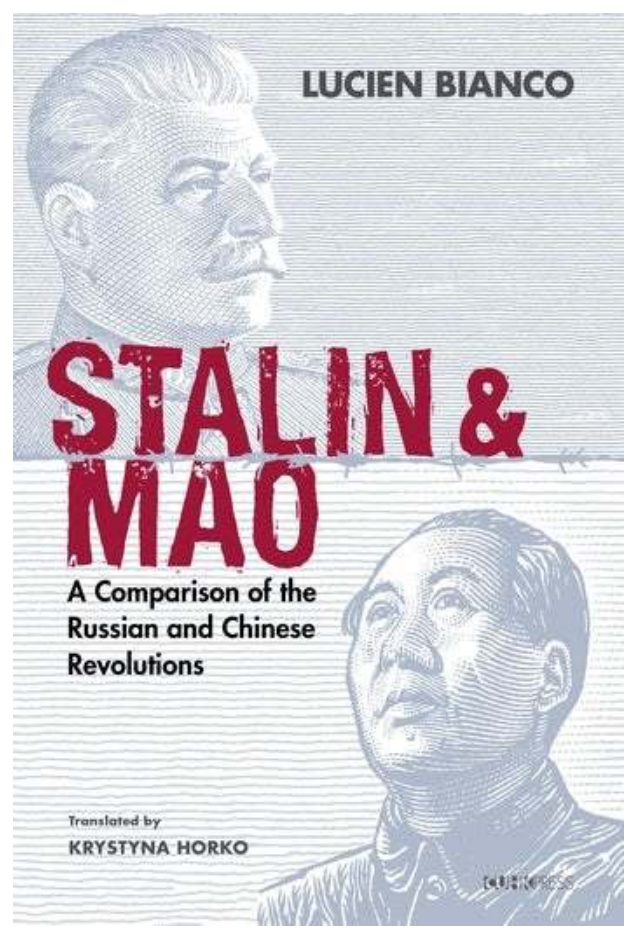
original. The title La récidive ("the recurrence" or "the repeat offence," as discussed by S. A. Smith, ${ }^{1}$ was rendered as Stalin and Mao, a title that downplays Bianco's critical point: the lack of originality of Mao's revolution and the persistence of the Stalinist model. In the same vein, Chapter 9 was defanged from 
"Monstres" ("monsters") to "Dictators"-a minor but significant change of tone, which may be due to the CUHK Press' efforts to publish relevant works on PRC history despite the narrowing scope of publishing freedom in Hong Kong in recent years.

3 The book is divided into nine monographic chapters. Bianco does not strive for thoroughness but instead focuses on select issues in which the history of both countries converged, consciously going against the current by not discussing either workers or the cities. He also leaves aside international relations and much of the global social, political, cultural, and environmental comparative context.

Chapter 1, "The Laggards," analyses the roots of the revolutionary upheavals in both Imperial Russia and Imperial and Republican China. According to Bianco, although China provided an even bleaker image of backwardness, both societies shared similar features: overwhelmingly rural economies, comparative poverty, small industrial sectors, rampant illiteracy, disturbing encounters with Western "modernity," the impact of global wars, and stagnant political systems.

5 Chapter 2, "Catching Up," summaries and compares the logic behind both systems, their achievements, and the costs incurred on their respective societies. Bianco shows that however ruthless both Stalin and Mao were, their main activities were directed toward transformation of the economy and the remodelling of society. Ultimately the results differed in the USSR and the PRC due to the divergence between the countries and the capacity of their leaders and administrations.

6 In the third chapter, "Politics," Bianco underlines the fundamental affinity of both regimes. Mao learned to be a communist from Stalin, and his only contact with the ideas of Lenin and Marx was through Stalin. That said, Bianco recognises two differences: Mao was much more given to the ideals of equality and rural revolution; and Mao was more of an ideological and distant ruler, while Stalin was a hands-on helmsman.

7 Chapters 4 and 5 provide a core for the argument in the book: the first deals with "The Peasants," the second with "The Famines." Bianco claims that although Chinese communists had a much stronger peasant base and greater knowledge of rural issues than their Soviet counterparts, the leadership of both parties came from the intelligentsia and did not represent any peasant interests. Neither revolution was a peasant revolution by any means. Moreover, communist in both the PRC and the USSR were disgusted with peasant culture, values, and economic practices. Both Mao and Stalin were suspicious of possible rural betrayal, but the degree of their barbarity in dealing with peasants differed: "Stalin mercilessly squeezed the peasants and in doing so killed them. Mao killed as many, if not more, by ignorance, arrogance, and insanity" (p. 114). Discussing the famines, Bianco replicates an already accepted argument that blames the leaders, the political system they constructed, and the developmental strategies 
they believed in for the horrendous starvation that hit both countries during their periods of ideologically driven accelerated growth (the Great Turn and the Great Leap Forward).

8 Chapter 6, devoted to "Bureaucracy," shows how the leaders in both countries largely gave in to a bureaucratisation of the political systems of their respective countries, effectively abandoning the idealist vision of rule by the proletariat. Here, however, a strong distinction existed between the USSR and the PRC, since Mao fought bureaucratism and instigated bouts of violence against cadres. Nevertheless, the political dynamic of both countries produced new privileged groups from the ranks of bureaucracy that were prone to careerism and corruption.

Chapter 7, "Culture," compares the problems and achievements of both countries in this field: how it fared with internationalism and nationalism, how it was controlled, and what was produced. Focusing on novels and novelists in both countries, Bianco sees some important works being written in the Soviet Russia and a dismal picture of what happened in China. Ultimately, the chapter is unfair to Chinese culture: novels were not the most important literary genre of the era, and other lively forms of artistic expression such short stories, opera, and poetry are ignored. Although Maoist cultural policy generally stifled artistic expression, it differed dramatically in the periods between 1949-1957, 1957-1966, and 1966-1976, and each of these times had its own distinct sub-periods. Moreover, the aesthetic value even of works created during the Cultural Revolution has been recognised by scholars. ${ }^{2}$

10 Chapter 8, "The Camps," compares the Soviet gulag to the Chinese laogai 勞改—a re-education-through-labour imprisonment system copied from the USSR with minor alterations. As the gulag is quite well studied, Bianco's analysis of laogai is valuable and interesting, clearly enunciating the main difference between them: the PRC's obsession with thought reform.

11 The last chapter, "The Dictators," summarises previous discussions and elaborates on the role of the leaders in shaping the Soviet and Chinese political systems. Bianco claims that it was the character and modus operandi of the leaders that left a lasting mark on the regimes. Thus, both Stalin and Mao, however different from other monstrous dictators of the twentieth century (he mentions Hitler and Pol Pot), were ultimately responsible for the disasters incurred on their respective societies.

12 Lucien Bianco's book is an invaluable piece of scholarship, and one that should be read and discussed. A few words of comment, however, are due. Without replicating the critique by S. A. Smith, I will stress different points. In his analysis Bianco does not take into consideration the many new findings from the field of economic history (especially rural) and historical anthropology that would render a much richer, though hardly comprehensive, view of the massive social and economic diversity of China. The centrality of the leaders in the analysis and the narrative overshadows many major actors and organisational forms, 
such as the Party and state apparatus. It remains for future scholars to pick up from where Bianco left and to examine the larger array of actors that shaped the Soviet and Chinese revolutions and regimes.

\section{NOTES}

1. S.A. Smith, "Lucien Bianco, La récidive, Révolution russe, révolution chinoise" (Lucien Bianco, The recurrence, Russian revolution, Chinese revolution), Cahiers du Monde Russe, Vol. 55, No. 3-4, 2014, pp. 1-7.

2. Paul Clark, The Chinese Cultural Revolution: A History, Cambridge, Cambridge University Press, 2008, $352 \mathrm{pp}$.

\section{AUTHOR}

\section{IGOR IWO CHABROWSKI}

Igor Iwo Chabrowski is Assistant Professor at the Institute of History of the University of Warsaw, Poland (igor.chabrowski@eui.eu). 